Kumawula, Vol. 4, No.1, April 2021, Hal 157 - 164

DOI: https://doi.org/10.24198/kumawula.v4i1.32431

ISSN 2620-844X (online)

Tersedia online di http://jurnal.unpad.ac.id/kumawula/index

\title{
PENGUATAN PEMBERDAYAAN MASYARAKAT KOMUNITAS LESTARI FARM DALAM MENJAGA KETAHANAN PANGAN MASA PANDEMI COVID-19
}

\author{
Novie Indrawati Sagita ${ }^{1^{*}}$, Nandang Alamsah Deliarnoor ${ }^{2}$, Dian Fitriani Afifah ${ }^{3}$ \\ ${ }^{1}$ Program Studi Administrasi Pemerintahan, Universitas Padjadjaran \\ ${ }^{2}$ Program Studi Ilmu Pemerintahan, Universitas Padjadjaran \\ ${ }^{3}$ Program Studi Administrasi Pemerintahan, Universitas Padjadjaran \\ *Korespondensi : novie.indrawati.sagita@unpad.ac.id
}

\begin{abstract}
The Lestari Farm Community was formed in order to deal with the Covid-19 Pandemic situation with the aim of maintaining family food security, and also improving the economy and welfare of residents. This community carries out agricultural and fishery cultivation activities. Since the community was formed, community involvement in cultivation activities has been very weak. The purpose of this outreach activity is to strengthen community empowerment and the commitment of members to achieve common goals. Extension activities to strengthen community empowerment are carried out online, given the Covid-19 situation which does not allow the team and participants to meet face-to-face. This activity begins with the preparation stage, namely data mining, and is followed up with an evaluation of the sustainability of Lestari Farm Community. This activity begins by discussing the factors that lead to weak community participation. This factor is due to the lack of proper implementation of the community empowerment stage, which begins with an inappropriate action plan formulation stage that impacts the implementation stage to the evaluation stage. The solution produced in this extension activity is the formulation of a model for strengthening community empowerment of the Lestari Farm Community, as well as an increase in communication forum activities that mutually strengthen knowledge, skills and motivate fellow members.
\end{abstract}

Keywords: community empowerment; food security; community participation

\begin{abstract}
ABSTRAK
Komunitas Lestari Farm dibentuk untuk menghadapi situasi Pandemi Covid-19 dengan tujuan menjaga ketahanan pangan keluarga, meningkatkan ekonomi dan kesejahteraan warga. Komunitas ini melakukan kegiatan budidaya pertanian dan perikanan. Sejak komunitas terbentuk, keterlibatan warga dalam kegiatan budidaya masih rendah. Tujuan kegiatan ini dilakukan untuk menguatkan pemberdayaan masyarakat pada Komunitas Lestari Farm dan dapat menguatkan komitmen anggota untuk mencapai tujuan bersama. Kegiatan penyuluhan penguatan pemberdayaan masyarakat dilakukan secara daring, mengingat situasi Covid-19 yang tidak memungkinkan tim dan peserta bertemu langsung secara tatap muka. Kegiatan ini diawali dengan tahap persiapan yakni penggalian data, dan ditindaklanjuti dengan kegiatan evaluasi mengenai keberlanjutan Komunitas Lestari Farm. Hasil dari kegiatan ini berupa mendiskusikan faktor-faktor yang menyebabkan rendahnya partisipasi warga. Faktor tersebut disebabkan karena tidak dilaksanakannya tahapan pemberdayaan masyarakat sebagaimana mestinya, yang diawali dengan tahap formulation action plan yang tidak sesuai sehingga berdampak pada tahap implementation hingga tahap evaluasi. Solusi yang dihasilkan pada kegiatan ini berupa penyusunan model penguatan pemberdayaan masyarakat Komunitas Lestari Farm, serta peningkatan kegiatan forum komunikasi yang saling menguatkan pengetahuan, ketrampilan dan memotivasi sesama anggota.
\end{abstract}

Kata Kunci: pemberdayaan masyarakat; ketahanan pangan; pasrtisipasi masyarakat 


\section{PENDAHULUAN}

Komunitas Lestari Farm merupakan kelompok warga masyarakat di Perumahan Griya Taman Lestari, Desa Gudang, Kecamatan Tanjung Sari, Kabupaten Sumedang. Warga perumahan ini sebagian besar memiliki mobilitas yang cukup tinggi karena bekerja jauh dari lokasi tempat tinggal seperti di wilayah Jatinangor, Cileunyi, Bandung, dan Sumedang, sebagai aparat pemerintah, karyawan swasta, pedagang, dan lainnya (Deliarnoer et al., 2020). Sejak pandemi Covid-19 dinyatakan masuk ke Indonesia bulan Maret 2020, kemudian ditindaklanjuti dengan penerapan PSBB di seluruh wilayah Indonesia termasuk Jawa Barat (Pusat Informasi dan Koordinasi Covid-19, 2020), memberikan dampak pada warga Perumahan Griya Taman Lestari. Berdasarkan hasil survey lapangan, aktivitas masyarakat yang semula cukup tinggi, berubah drastis menjadi aktivitas yang semua dikerjakan dari rumah, pemerintah menghendaki masyarakat tinggal dan bekerja dari rumah (stay at home and work from home). Tidak hanya bekerja dari rumah, namun ada juga sebagian dari warga tersebut terpaksa dirumahkan bahkan ada yang sampai diberhentikan. Masyarakat yang berprofesi sebagai pedagang, juga mengalami penurunan keuntungan, karena pembeli mulai berkurang. Kebijakan pemerintah kepada masyarakat untuk melakukan semua aktivitas, bekerja dan belajar dari rumah, tidak bisa dipungkiri menyebabkan kebosanan, kecemasan, dan meningkatnya stress yang dialami warga.

Menurut Ketua RW 09 Bapak Riyadi, selaku ketua komunitas Lestari Farm Perumahan Griya Taman Lestari, pada wawancara yang dilaksanakan pada tanggal 23 Juli 2020 melalui platform Zoom Meeting, kondisi pandemi ini, tidak bisa hanya sekedar disesali atau dikeluhkan oleh warga, namun mereka berusaha beradaptasi menghadapi tantangan Pandemi Covid-19. Tekad tersebut akhirnya melahirkan sebuah gagasan membentuk Komunitas Lestari Farm, yang memanfaatkan pekarangan rumah dan lahan kosong disekitar lingkungan tenpat tinggal untuk budi daya pertanian dan perikanan. Komunitas ini membentuk kelompok untuk bersama-sama belajar dan mempraktekkan budidaya sayuran hidroponik, ikan air tawar (lele, ikan nila, dan ikan emas) serta budidaya ikan hias. Ditambahkan pula oleh bapak Iwang Gumelar, pada kegiatan wawancara di waktu yang sama, bahwa tujuan komunitas Lestari Farm ini bukan sekedar memanfaatkan lahan pekarangan rumah dan lahan kosong sekitar rumah tinggal mereka, melainkan juga untuk memenuhi kebutuhan konsumsi pangan keluarga. Harapan kedepan, Komunitas Lestari Farm menghendaki hasil pertanian tersebut dapat menambah penghasilan masyarakat dengan menjual hasil budidaya tanaman dan ikan tersebut ke pasar, konsumen, warung, maupun rumah makan sekitar sehingga dapat meningkatkan perekonomian dan kesejahteraan warganya.

Pada wawancara yang dilakukan melalui platform Zoom Meeting tersebut, diketahui bahwa pembentukan Komunitas Lestari Farm ini awalnya diinisiasi oleh Ketua RW 09 Bapak Riyadi dan difasilitasi oleh salah satu dosen Kelautan Unpad Dr. Ir. Iwang Gumilar, M.Si. Pada awalnya warga masyarakat yang menjadi anggota komunitas ini bersemangat melakukan kegiatan budidaya pertanian dan perikanan, namun ditengah perjalanan, semangat masyarakat mulai berkurang dalam melakukan aktivitas budidaya. Hal ini disebabkan karena tidak semua warga yang berhasil melaksanakan budidaya sehingga dapat memanen hasil yang memuaskan. Meskipun pelatihan budidaya pertanian dan perikanan telah diberikan oleh fasilitator, namun tidak semua anggota komunitas melakukan dan terampil mengamalkan ilmu pengetahuan yang diperolehnya. Ketidakberhasilan inilah yang menyebabkan Komunitas Lestari Farm masih jauh meraih mimpi-mimpinya untuk memberdayakan masyarakat agar dapat mencapai kemandirian pangan keluarga apalagi mimpi untuk meningkatkan perekonomian dan kesejahteraan warga.

Permasalahan sebagaimana dikemukakan di atas, menunjukkan masih lemahnya pemberdayaan masyarakat akibat ikatan komunitas dalam mencapai tujuan bersama tidak terlalu kuat. Sehubungan dengan hal tersebut, maka kami, tim dosen yang mendapat hibah dari Universitas Padjadjaran melalui skema Academic Leadership Grant (ALG) dibawah binaan Prof. Dr. Nandang Alamsah 
Deliarnoor, S.H., M.Hum melakukan Kegiatan Pengabdian dan Pemberdayaan Masyarakat (PPM) dengan memberikan materi tentang Penguatan Pemberdayaan Masyarakat dalam Komunitas Lestari Farm. Tujuan dari dilakukannya kegiatan ini agar pemberdayaan masyarakat yang sudah terbangun memiliki ikatan yang semakin kuat agar dapat mencapai tujuan mulia warga yang tergabung dalam Komunitas Lestari Farm.

\section{METODE}

Metode kegiatan Pengabdian dan Pemberdayaan Masyarakat ini dalam bentuk memberikan penyuluhan kepada Komunitas Lestari Farm yang dilaksanakan secara daring sehubungan masih dalam suasana Pandemi (Covid-19) yang tidak memungkinkan adanya pertemuan dan interaksi langsung dengan peserta. PPM daring menggunakan platform Google Meet dan Zoom. Ada tiga tahapan yang dilakukan tim sebelum melaksanakan PPM Webinar, yakni tahap persiapan yang mengundang inisiator yaitu Ketua RW 09 selaku pimpinan Komunitas Lestari Farm. Pada tahap ini, tim melakukan identifikasi dan pengumpulan data berupa lokasi, jumlah dan karakter warga. Kedua, tahap pelaksanaan, yakni melaksanakan kegiatan PPM virtual yakni Penyuluhan tentang Penguatan Pemberdayaan Masyarakat dalam Komunitas Lestari Farm pada Webinar Seri 2 yang dilaksanakan pada hari Senin, 27 Juli 2020, diikuti oleh sekitar 30 warga anggota komunitas Lestari Farm. Ketiga, adalah tahap evaluasi kegiatan, yang mana pada tahap ini tim membahas tindak lanjut kegiatan PPM berupa pemantauan pemberdayaan masyarakat.

\section{HASIL DAN PEMBAHASAN}

Pada saat pertemuan pertama (tahap persiapan), beberapa masalah dibahas terkait kondisi pemberdayaan masyarakat di Komunitas Lestari Farm, sebagai berikut :

a. Ketidaktekunan sebagian warga dalam melakukan budidaya pertanian dan perikanan

b. Umumnya warga ingin segera merasakan hasil secara instan (cepat) dan tidak sabar melaksanakan proses budidaya tersebut.

c. Rendahnya tanggung jawab sebagian warga untuk memelihara tanaman dan peternakan ikan yang ada di lahan umum disekitar tempat tinggal mereka.

d. Adanya beberapa anggota komunitas yang tidak mau bersusah payah ikut memelihara tanaman dan budidaya ikan, tetapi giliran ada panen bersama, warga tersebut ingin merasakan hasilnya lebih dulu daripada warga lain yang justru memeliharanya dengan baik.

e. Adanya rasa iri dari warga yang tidak berhasil kepada warga yang berhasil memanen hasil budi dayanya.

Pada tahap pelaksanaan, dilakukan kegiatan penyuluhan tentang Penguatan Pemberdayaan Masyarakat dalam Komunitas Lestari Farm. Kegiatan ini diawali dengan penjelasan tentang definisi pemberdayaan masyarakat. Hal ini perlu dilakukan, agar warga anggota komunitas memahami makna dan tujuan dari komunitas yang mereka dirikan.

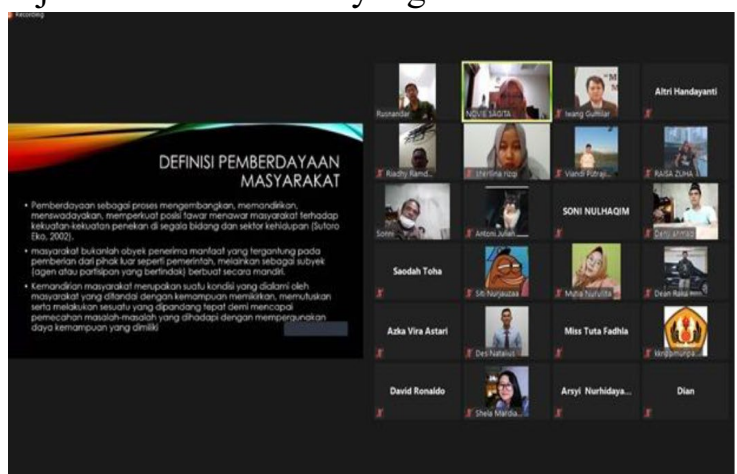

Gambar 1. Kegiatan Daring Penyuluhan

Penguatan Pemberdayaan Masyarakat pada Komunitas Lestari Farm

Sumber : Dokumen ALG, kegiatan penyuluhan melalui Zoom Meeting, 27 Juli 2020

Pemberdayaan masyarakat merupakan upaya pelibatan masyarakat dengan merangkum nilai-nilai lokal masyarakat sehingga pembangunan yang dilaksanakan bersifat people centered, participatory, empowerment and sustainable (Chambers, 1994). Pemberdayaan masyarakat menjadi bagian dari paradigma pembangunan manusia (People Centered Development Paradigm). 
Seperti kita tahu, ada tiga perkembangan paradigma pembangunan, yakni paradigma pertumbuhan, paradigma kesejahteraan, dan paradigma pembangunan manusia. Pada tahun 1980-an, negara-negara berkembang dan negara baru umumnya menganut paradigma pertumbuhan, dimana upaya yang dilakukan pemerintah semata-mata mengejar pertumbuhan ekonomi dan melakukan modernisasi. Namun paradigma ini ternyata justru semakin memperlebar kesenjangan ekonomi dan sosial, karena pertumbuhan ekonomi yang tinggi lebih berpihak pada kelompok masyarakat pemilik modal dan memarjinalisasi masyarakat yang memiliki sumber daya dan akses ekonomi yang terbatas, sehingga semakin memiskinkan masyarakat. Oleh karena itu, lahir paradigma kesejahteraan (welfare paradigm) yang menyadarkan pemerintah bahwa dalam melaksanakan pembangunan jangan hanya berambisi mengejar pertumbuhan ekonomi semata melainkan pembangunan harus senyatanya berorientasi pada peningkatan kesejahteraan masyarakat. Namun, paradigma ini justru menambah beban pemerintah yang harus terus menerus mengurus dan melayani warganya, ditengah-tengah keterbatasan pengelolaan sumber daya ekonomi dan anggaran oleh negara. Oleh karena itu, terbitlah paradigma baru yakni paradigma pembangunan manusia yang menghendaki pemerintah jangan hanya "menyuapi" masyarakat melainkan harus memberdayakan warga masyarakatnya agar menjadi mandiri dan bahkan dapat berkontribusi dalam kemajuan pembangunan. Oleh karena itu, Chambers berpendapat bahwa dengan pemberdayaan masyarakat dapat menghasilkan pembangunan yang berkelanjutan, dan masyarakat merasa menjadi bagian dari pembangunan tersebut karena mereka dilibatkan secara luas (Chambers, 1994).

Konsep pemberdayaan masyarakat menjadi bagian dari konsep pembangunan yang tercantum dalam kebijakan pembangunan di Indonesia. UU Nomor 23 Tahun 2014 didalamnya juga mengatur tentang kewenangan pemerintah daerah dalam melakukan pemberdayaan masyarakat sebagai salah satu urusan pemerintahan wajib yang tidak berkaitan dengan pelayanan dasar. Menurut Sutoro Eko, pemberdayaan masyarakat bertujuan mewujudkan pembangunan partisipatif, people oriented, dan berkelanjutan karena dalam proses pemberdayaan tersebut terjadi proses pengembangkan kapasitas ketrampilan hidup masyarakat sehingga menciptakan masyarakat yang mandiri, mampu mengatasi permasalahan pembangunan di wilayahnya secara swadaya, dan juga memperkuat posisi tawar menawar masyarakat terhadap kekuatan-kekuatan penekan di segala bidang dan sektor kehidupan (Eko, 2002). Penguatan pemberdayaan masyarakat untuk ikut serta dalam pembangunan dirasakan lebih efektif, karena pencapaian tujuan pembangunan sesuai dengan kehendak dan kebutuhan masyarakat. Oleh karena itu, melalui pemberdayaan, masyarakat memperoleh pengalaman merancang, melaksanakan, sekaligus mempertanggungjawabkan programprogam yang dapat meningkatkan kemampuan diri dan ekonomi mereka (Solihah, 2020).

Paradigma Pembangunan Manusia memandang masyarakat bukan sebagai obyek penerima manfaat yang tergantung pada pemberian dari pihak luar seperti pemerintah, melainkan sebagai subyek (agen atau partisipan yang bertindak) yang mampu berbuat secara mandiri, memikirkan, memutuskan serta melakukan sesuatu yang dipandang tepat demi mencapai pemecahan masalah-masalah yang dihadapi dengan mempergunakan daya kemampuan yang dimiliki. Oleh karena itu pemberdayaan masyarakat Lestari Farm ini menjadi penting agar kegiatan budi daya pertanian dan perikanan yang sudah dilakukan dapat menjadi berkelanjutan, membantu mewujudkan kemandirian pangan, sekaligus masyarakat secara swadaya mampu mengatasi permasalahan-permasalahan di masa yang akan datang, misalnya terjadi masalah krisis ketersediaan pangan.

Setiap pemberdayaan masyarakat pasti ada peran aktor didalamnya (Luttrell et al., 2009), misalnya aparat pemerintah, civitas perguruan tinggi, lembaga swadaya masyarakat, pers, partai politik, lembaga donor, actor-aktor masyarakat sipil, atau oleh 
organisasi masyarakat lokal sendiri. Aktoraktor di luar kelompok masyarakat yang bergabung dalam komunitas dapat menjadi fasilitator atau tenaga pendaping sedangkan aktor pemberdayaan masyarakat yang berasal dari komunitas pemberdayaan itu sendiri sebagai tenaga kader lokal (indigenous worker). Pemberdayaan masyarakat dapat semakin kuat bilamana dalam aktor-aktor yang terlibat didalamnya memiliki 4 (empat) ketrampilan (Ife, 1995; Zastrow, 2010), yakni :

- Ketrampilan fasilitatif (aktivis, initiator, group fasilitator, organizing), aktor ini harus memiliki kemampuan menginisiasi kegiatan, memfasilitasi pembentukan komunitas, dengan mengorganisir kegiatan kelompok.

- Ketrampilan edukasional (enabler, empower, educator),aktor ini memiliki kemampuan transfer pengetahuan, mendidik, dan meningkatkan pengetahuan dan ketrampilan anggota kelompok yang diberdayakan.

- Ketrampilan perwakilan (broker, advokasi, mediator, negotiator, coordinator, public speaker), aktor ini bertugas sebagai perantara, mediator, negosiator, juru bicara yang mewakili kelompok dengan pihak-pihak luar yang berkepentingan atau dalam kerjasama. Aktor ini pula sekaligus bertugas melakukan mediasi dan advokasi bilamana terjadi tekanan atau gangguan dari pihak-pihak lain.

- Ketrampilan teknis (researcher, administrator), aktor ini bertugas melaksanakan tugas-tugas yang bersifat administratif yang dibutuhkan oleh komunitas, termasuk pembuatan proposal ataupun mengatur perbendaharaan.

Pada Komunitas Lestari Farm, aktoraktor yang terlibat belum berperan secara menyeluruh dan sebagaimana mestinya. Pelaksanaan peran dalam komunitas Lestari Farm banyak mengandalkan Ketua RW sebagai aktor yang menginisiasi terbentuknya komunitas dan fasilitator (dari perguruan tinggi) yang memberikan edukasi pengetahuan dan ketrampilan kepada warga mengenai tata cara budidaya pertanian dan perikanan. Anggota komunitas yang aktif terlibat kegiatan budidaya tersebut hanya sekitar 15-20 orang di RT 02 RW 09, padahal jumlah rumah tangga yang ada di RT tersebut setidaknya minimal mencapai 50 kepala keluarga (KK). Jumlah warga yang masih sedikit berpartisipasi dalam komunitas menunjukkan aktor-aktor yang terlibat dalam Komunitas Lestari Farm belum melaksanakan perannya secara optimal. Hal ini disebabkan karena pada saat pembentukan komunitas, tidak ada pembagian tugas dan peran para anggotanya. Kegiatan penyuluhan ini menyadarkan komunitas akan perlunya pembagian peran antar aktor-aktor tersebut, sehingga mereka dapat memperkuat ketrampilan yang perlu dimiliki sesuai perannya.

Dalam membangun pemberdayaan masyarakat umumnya dilakukan dengan berbagai tahapan (Adi, 2002), yakni :

- Tahap engagement, yakni tahapan pengikatan antar anggota kelompok yang biasanya terbentuk karena adanya kesamaan kepentingan dan tujuan.

- Tahap assesment, yakni tahapan dimana anggota kelompok menilai dan menyepakati berdirinya suatu komunitas.

- Tahap planning, yakni tahapan dimana anggota kelompok merencanakan kegiatan-kegiatan yang akan dilakukan dalam rangka mencapai tujuan komunitas.

- Tahap formulation action plan, yakni tahapan rumusan rencana aksi yang akan dilakukan, pada tahapan ini pemimpin kelompok, dibantu tenaga pendamping/fasilitator dan kader lokal bersama anggota kelompok lainnya, berbagi tugas dan kewajiban masing-masing anggota, merumuskan tugas masing-masing anggota (job description) 
- Tahap implementation, yakni tahapan pelaksanaan kegiatan yang mana masing-masing anggota bertanggung jawab dalam pelaksanaan tugas dan kewajibannya dengan sukarela dan sungguh-sungguh.

- Tahap evaluation, yakni tahap evaluasi pelaksanaan kegiatan sesuai tugas dan kewajibannya.

- Tahap termination, yakni tahap keputusan dari hasil evaluasi apakah komunitas tersebut dapat diteruskan atau dihentikan.

Berdasarkan hasil diskusi dalam kegiatan penyuluhan, lemahnya pemberdayaan masyarakat di Komunitas Lestari Farm disebabkan karena tidak dilakukannya tahap formulation action plan dengan baik. Setelah komunitas ini merencanakan untuk melakukan kegiatan budidaya pertanian dan perikanan, dengan kesepakatan pelaksanaan kegiatan dilaksanakan secara bersama-sama. Selama pelaksanaan kegiatan budi daya, tidak banyak anggota yang terlibat, melainkan hanya Ketua RW dan beberapa anggota saja. Hal ini disebabkan pada tahap perencanaan, ketua kelompok komunitas tidak melakukan pembagian tugas dan tanggung jawab diantara anggota. Sehingga pada tahap implementasinya, sesama anggota cenderung saling mengandalkan satu sama lain dan tidak memiliki komitmen untuk aktif dalam kegiatan budidaya. Meskipun ketua komunitas telah melakukan rapat evaluasi mengenai ketidakaktifan beberapa anggota dan tidak berjalannya kegiatan budidaya sesuai rencana, namun evaluasi tersebut tidak menemukan jawaban mengenai faktor penyebab lemahnya partisipasi sebagian warga dalam kegiatan budidaya tersebut. Meskipun demikian, beberapa anggota memutuskan bahwa komunitas ini masih penting untuk dipertahankan karena memiliki tujuan yang mulia dan sangat baik bagi kemaslahatan warga.

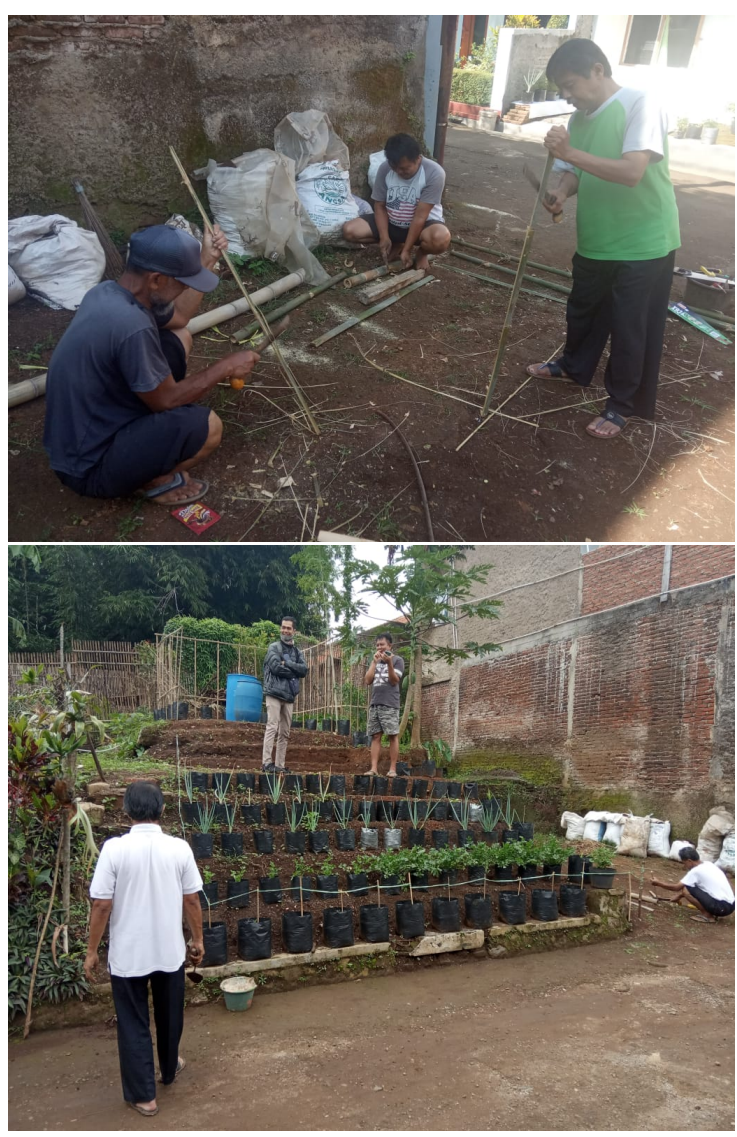

\section{Gambar 2. Kegiatan Pemanfaatan Lahan Untuk Budidaya Pertanian oleh Komunitas Lestari Farm \\ Sumber : Arsip Komunitas Lestari Farm}

Pada kegiatan penyuluhan, didiskusikan pula mengenai faktor-faktor yang mempengaruhi kuat atau lemahnya ikatan dalam kelompok pemberdayaan masyarakat, yang dilihat dari modal yang dimiliki oleh Komunitas Lestari Farm. Terdapat 2 (dua) modal dalam pemberdayaan masyarakat yaitu modal material (terdiri dari kemampuan finansial dan sarana prasarana pendukung) dan modal immaterial (terdiri dari manusia/SDM dan nilai-nilai budaya yang berlaku pada suatu masyarakat). Modal material dibutuhkan untuk mendukung kelancaran kegiatan pemberdayaan masyarakat. Namun yang lebih penting daripada modal material adalah modal immaterial, yang mana meskipun finansial dan sarana prasarana yang dimiliki komunitas sangat terbatas, namun kapasitas yang tinggi yang dimiliki manusia anggotanya mampu mengatasi keterbatasan modal material tersebut. Begitupula halnya dengan nilai-nilai budaya masyarakat setempat. Pemberdayaan 
masyarakat dapat berjalan lancar bilamana kegiatan dan dampak perubahan yang dihasilkannya tidak bertentangan dengan nilainilai sosial budaya yang diyakni masyarakat tersebut.
Sensitivitas pemimpin sangat dibutuhkan untuk peka terhadap masalah yang dihadapi komunitas. Kehadiran pemimpin diantara anggota sangat penting untuk mengetahui potensi yang dimiliki anggota agar

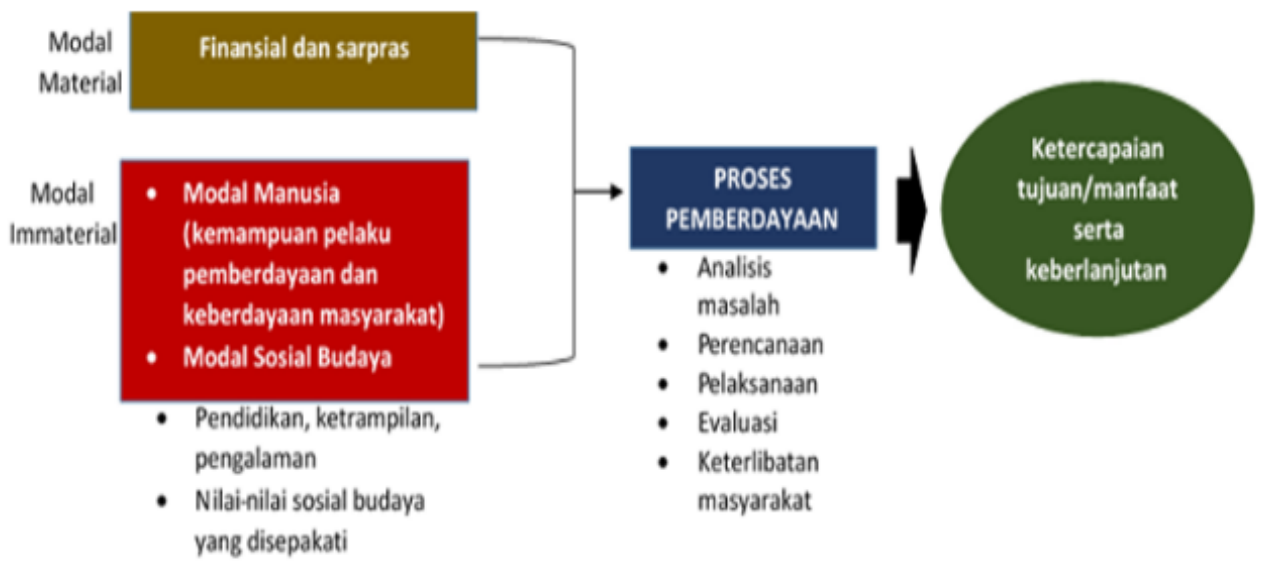

\section{Gambar 3. Model Penguatan Pemberdayaan Masyarakat Komunitas Lestari farm}

Sumber : diadaptasi dari Ife, 1995; Zastrow, 2010

Pada kasus Komunitas Lestari Farm, kedua modal tersebut tidak terlalu mendukung, terutama modal material (baik dukungan finansial maupun sarana prasarana), dan lemah pada modal immaterial (terutama keterbatasan pengetahuan dan ketrampilan sebagian anggota komunitas). Permasalahan pemberdayaan masyarakat dalam Komunitas Lestari Farm ditandai dengan gejala rendahnya partisipasi beberapa anggota masyarakat terlibat dalam kegiatan budidaya pertanian dan perikanan, namun kelompok yang tidak aktif ini ingin ikut merasakan jerih payah anggota lain, sehingga hal ini rentan menimbulkan konflik internal dalam komunitas tersebut. Dalam penyuluhan ini, menyarankan kepada ketua Komunitas Lestari Farm untuk mencoba memahami mengapa terdapat beberapa anggota yang memiliki partisipasi yang rendah dalam kegiatan budidaya. Rendahnya partisipasi sebagian anggota tersebut bisa jadi disebabkan oleh dua hal, yakni rendahnya pengetahuan dan ketrampilan anggota dalam melaksanakan budidaya sehingga mereka merasa apa yang dilakukannya tidak akan berhasil, disamping memang masih rendahnya komitmen untuk mencapai tujuan bersama-sama. dapat dioptimalkan (Darwis et al., 2020). Oleh karena itu, ketua Komunitas Lestari Farm perlu mengupayakan kegiatan sharing of knowledge dan interaksi antar anggota yang lebih intensif, yang mana pada kegiatan tersebut, anggota yang memiliki pengetahuan lebih atau fasilitator/tenaga pendamping melakukan edukasi yang menambah pengetahuan dan ketrampilan anggota lain secara merata. Selain itu, ketua Komunitas Lestari Farm perlu melakukan forum tukar pendapat di antara anggota hingga menyampaikan keluhan atau hal-hal yang tidak berkenan, sehingga dapat diketahui kesulitan yang dialami anggota, sekaligus ketua dan sesama anggota dapat saling memotivasi agart keterlibatan anggota menjadi meningkat. Hal ini dapat dilakukan sepanjang komunitas memegang prinsip-prinsip pemberdayaan masyarakat yakni saling percaya dan menghormati, kesetaraan, musyawarah, demokratis, kekeluargaan, kebersamaan, dan keterbukaan.

\section{SIMPULAN}

Komunitas Lestari Farm memiliki tujuan yang baik yakni mewujudkan kemandirian pangan keluarga, meningkatkan ekonomi dan kesejahteraan anggotanya. Namun pada kenyatannya, tujuan ini menghadapi 
kendala, ketika beberapa anggota tidak terlibat aktif dalam kegiatan budidaya, dan rentan konflik karena beberapa perilaku anggota yang tidak aktif mengganggu kenyamanan anggota lain.

Faktor yang menyebabkan lemahnya pemberdayaan masyarakat dalam Komunitas Lestari Farm tersebut disebabkan karena tidak dilaksanakannya tahapan pemberdayaan masyarakat dengan baik (terutama tahapan formulation action plan yang berimbas pada terganggunya tahapan implementasi, hingga tahap evaluasi yang belum solutif).

Upaya penguatan pemberdayaan masyarakat dalam Komunitas Lestari Farm tersebut dapat dilakukan dengan mengetahui modal pemberdayaan masyarakat baik modal material dan modaal immaterial. Hal yang lebih penting dilakukan oleh Komunitas Lestari Farm adalah dengan meningkatkan modal manusia yang memiliki peran kunci dalam pemberdayaan masyarakat. Dalam proses pemberdayaan, dimana keterlibatan anggota rendah maka diperlukan sharing knowledge dan intensitas interaksi yang lebih tinggi sehingga antar anggota dapat secara terbuka mengemukakan kesulitan yang dihadapi anggota, selain itu dalam pemberdayaan masyarakat penting bagi anggota-anggota untuk berpegang pada prinsip yang disepakati bersama oleh anggota komunitas.

\section{UCAPAN TERIMA KASIH}

Ucapan terima kasih disampaikan kepada Bapak Riyadi selaku Ketua RW 09 Desa Gudang Kecamatan Tanjungsari Kabupaten Sumedang dan Bapak Dr. Ir. Iwang Gumilar, M.Si sebagai pelatih budidaya pertanian dan perikanan yang telah memfasilitasi kegiatan diskusi dan penyuluhan dengan Komunitas Lestari Farm.

\section{DAFTAR PUSTAKA}

Adi, I. R. (2002). Pemikiran-Pemikiran dalam Pembangunan Kesejahteraan Sosial. Lembaga Penerbit Fakultas EkonomiUniversitas Indonesia.

Chambers, R. (1994). 'Participatory Rural Appraisal (PRA): Analysis and Exper. World Development, 22(10).
Darwis, R. S., Resnawaty, R., \& Nuriyah, E. (2020). Peningkatan Sensitivitas

Kepemimpinan Lokal dalam Pengelolaan Sungai Citarum melalui Teknik Participatory Rural Appraisal (PRA) di Desa Rancamayar.

Kumawula : Jurnal Pengabdian Kepada Masyarakat, 3(1).

http://jurnal.unpad.ac.id/kumawula/articl e/view/24820/pdf

Deliarnoer, N. A., Nulhaqim, S. A., Gumilar, I., \& Sagita, N. I. (2020). Laporan PKM Academic Leadership Grant (ALG) : Pengembangan Komunitas Peternakan, Perikanan dan Pertanian Rumahan Dalam Menghadapi Krisis Pangan Masa Pandemi.

Eko, S. (2002). Pemberdayaan Masyarakat. Badan Diklat Provinsi Kalimantan Timur.

Ife, J. (1995). Community Development: Creating Community Alternatives, Vision, Analysis and Practice. Longman.

Luttrell, C., Quiroz, S., Scrutton, C., \& Bird, K. (2009). Understanding and Operationalising Empowerment (No. 308).

https://www.odi.org/sites/odi.org.uk/file s/odi-assets/publications-opinionfiles/5500.pdf

Pusat Informasi dan Koordinasi Covid-19. (2020). Respon Kebijakan Pemprov Jawa Barat dalam Menanggulangi Wabah Covid-19.

Solihah, R. (2020). Pemberdayaan Masyarakat Melalui Pemanfaatan Pekarangan sebagai Warung Hidup Keluarga di Desa Kutamandiri Kecamatan Tanjungsari. Kumawula : Jurnal Pengabdian Kepada Masyarakat, 3(2).

http://jurnal.unpad.ac.id/kumawula/articl e/view/26436/pdf

Zastrow, C. (2010). Introduction to Social Work and Social Welfare (Eight). Brook/Cole Publishing Co. 